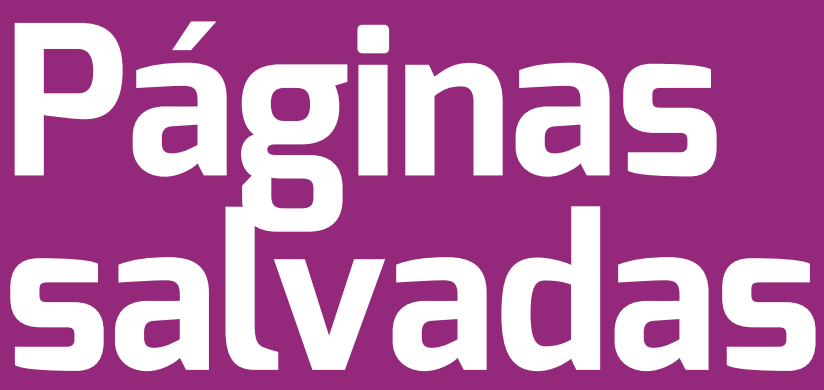

\title{
Memoria, tres voces que no callan
}

Colectivo \#NosFaltan3

rrivasb国yahoo.com alesita.rivas20@gmail.com

Recibido: 1 de octubre de 2019 |Aceptado: 15 de octubre de 2019 Dol: https://doi.org/10.18272/pd.v3i1.1566 Referencia de este artículo: Colectivo \#NosFaltan3 (2019). Memoria, tres voces que no callan. \#PerDebate, volumen 3 (pp. 268-292). Quito: USFQ Press.

El Colectivo \#NosFaltan3 se formó en marzo de 2018 tras el secuestro del equipo periodístico del diario El Comercio en la frontera norte de Ecuador. Su misión es recordar a las tres personas asesinadas y demandar memoria, verdad y justicia. La iniciativa reúne a periodistas, amigos y familiares de las víctimas. 
Los colores no existen, sino la luz. Las fotografías son pinceladas de luz que un artista alcanza a ver y las captura con su cámara. La mirada sensible de Paúl Rivas Bravo advertía imágenes ahí donde la oscuridad las escondía. Nos permitía entender a los rostros y a las historias con más claridad. Paúl lo decía: fotografiar es pintar con luz. El clic de su cámara congelaba la imagen en el instante preciso, cuando la luz descubría las texturas de aquello que andaba buscando: la realidad. A Paúl le interesaba mostrar las problemáticas sociales y el rostro y la cotidianidad de las personas sencillas.

A Javier Ortega Reyes le apasionaba la investigación periodística. Podía pasar días sumergido en montañas de papeles hasta encontrar los datos precisos para sustentar un reportaje. Pero también tenía el carisma para acercarse a la gente, ganar su confianza y escuchar su historia, para luego escribirla en las páginas de El Comercio. Prefería escribir en las noches, por eso solía ser de los últimos en dejar la redacción. Así armaba grandes rompecabezas, con piezas halladas entre las fuentes oficiales, sus fuentes de confianza y lo que le contaba la gente que conocía en cada calle que visitaba para humanizar sus trabajos.

En dieciséis años como conductor de El Comercio, Efraín Segarra Abril aprendió a ser el complemento perfecto para los equipos con los que trabajaba. Era puntual, sonriente y siempre dispuesto a ayudar. En el periódico, fotógrafos, periodistas, diseñadores y personal administrativo lo recuerdan como una figura paterna y un reportero más, que estaba atento a lo que sus compañeros no podían ver mientras entrevistaban o fotografiaban otros puntos de una misma escena.

El 26 de marzo del 2018, Paúl, Javier y Efraín fueron secuestrados en Mataje-Ecuador por integrantes del grupo Oliver Sinisterra, una columna disidente de las Fuerzas Armadas Revolucionarias de Colombia (FARC) que implanta el terror en el borde fronterizo norte del país. Días después fueron asesinados en la selva del sur de Colombia en medio de acciones incongruentes de las autoridades. En Ecuador y Colombia se encuentran abiertas investigaciones por el delito de secuestro y homicidio. Mientras tanto en la Comisión Interamericana de Derechos Humanos (CIDH) se instaló un mecanismo especial de seguimiento a las fiscalías de ambos países para determinar responsabilidades en todos los niveles, incluyendo la posible participación de agentes estatales por acción u omisión en los hechos suscitados. 
Cuando hechos tan desgarradores como ese ocurren, la lógica de lo instituido insiste en que lo mejor es el olvido, más aún cuando las circunstancias del crimen advierten que existen verdades que quieren ser acalladas; más aún cuando los operadores de justicia dejan pasar los días, inmóviles, mientras convocan a la impunidad.

Sin embargo, los familiares, amigos, colegas de Paúl, Javier y Efraín, y quienes se han conmovido frente a su asesinato, hacen suyas las palabras del historiador Yosef Yerushalmi, cuando expresa que:"Si me es dado elegir, me pondré del lado del 'exceso' de historia, tanto más poderoso es mi terror al olvido que el temor de tener que recordar demasiado" y en un ejercicio de memoria han recogido lo mejor del trabajo de los tres, durante su permanencia en el diario El Comercio para presentarlo a modo de exposición itinerante, cuyo objetivo es recordarle al país, al continente y al mundo, que las balas de los criminales y la desidia de los Estados no son suficientes para acallar sus voces.

Las imágenes que acompañan a estas páginas son la muestra de una realidad que saltó a la luz con el secuestro del equipo periodístico de El Comercio: la frontera norte es un rincón de la patria en el que las oportunidades parecen estar ligadas - en su gran mayoría - a la economía del narcotráfico; la presencia policial y militar no es suficiente para garantizar seguridad; medios y periodistas no fuimos capaces de advertir lo que ahí pasaba pese a que los textos, las fotos, los recorridos nos daban las señales del peligro; las autoridades prefirieron el silencio cómplice.

'Tres voces que no callan' nos habla también de las posibilidades de la memoria como reivindicación y como instrumento para evitar la repetición, pone en escena la importancia del trabajo periodístico en contextos de alta sensibilidad, porque a pesar de todo, aquellas son zonas en las que la gente se aferra a la vida, sonríe, se esfuerza y mantiene la esperanza de no caer en el olvido. Y por eso, estas imágenes recuerdan además la enorme necesidad de reportear con estrategia, exigiendo la garantía de derechos en una cobertura, para que las historias puedan seguir siendo contadas.

Los pasillos de la CIDH en Washington, los festivales de fotografía al aire libre de Nueva York, los auditorios de universidades en Ecuador, los salones municipales de múltiples ciudades, salas de arte y varios espacios más se han convertido en el escenario de trabajos diversos y de las muestras 'El pintor de luz', su versión actualizada 'Nos faltan 3'y 'Tres voces que no callan'. Esperamos que en las páginas de este libro, que debaten sobre el desafío y la necesidad de la cobertura de frontera, logren el propósito de alentar a un periodismo mejor preparado para las problemáticas que enfrenta el mundo.

Porque, aunque siempre nos faltarán tres, hacer memoria de quienes fueron Paúl, Javier y Efraín y lo que nos dejaron como legado puede ser un gran paso para evitar que otros periodistas les falten a sus familias y a sus redacciones. Porque mientras sigamos teniendo Memoria, seguiremos pidiendo Verdad y Justicia. 


\section{LOS TRES}
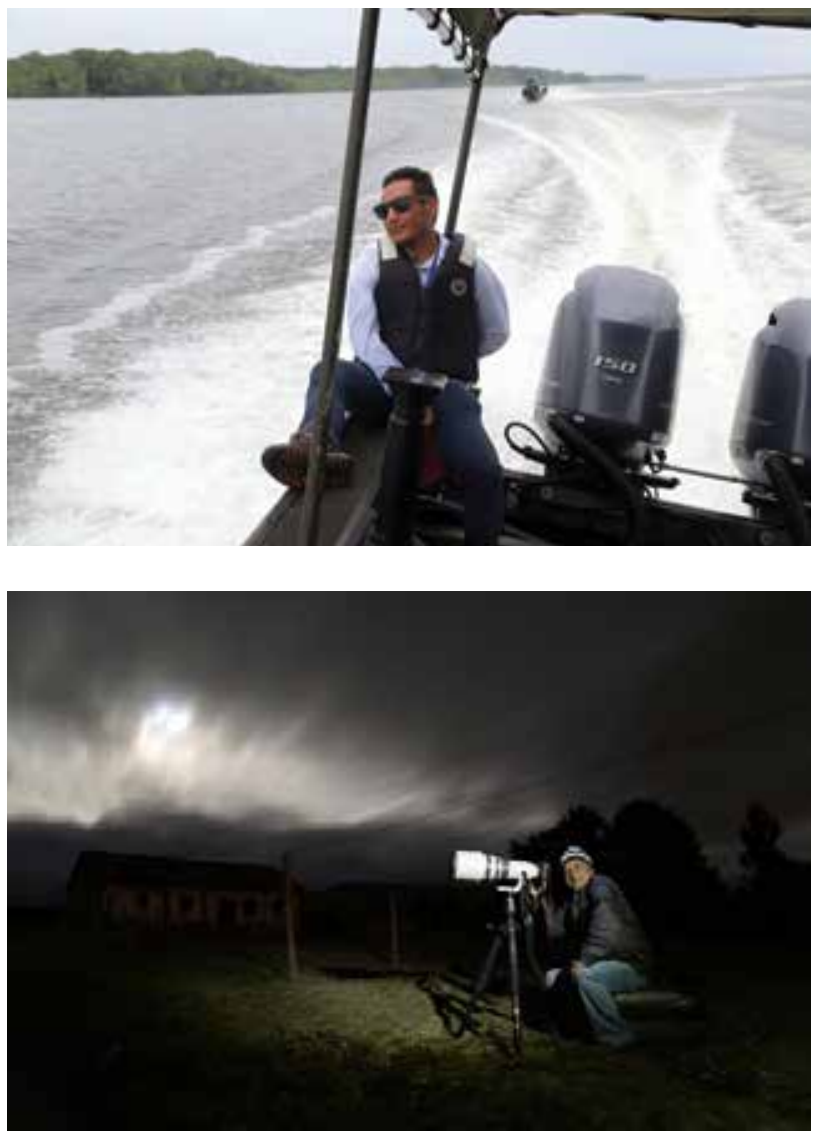

Efraín Segarra

Foto de Diego Pallero Torres / El Comercio
Javier Ortega Reyes

Foto de Diego Pallero Torres / El Comercio Esmeraldas, Ecuador

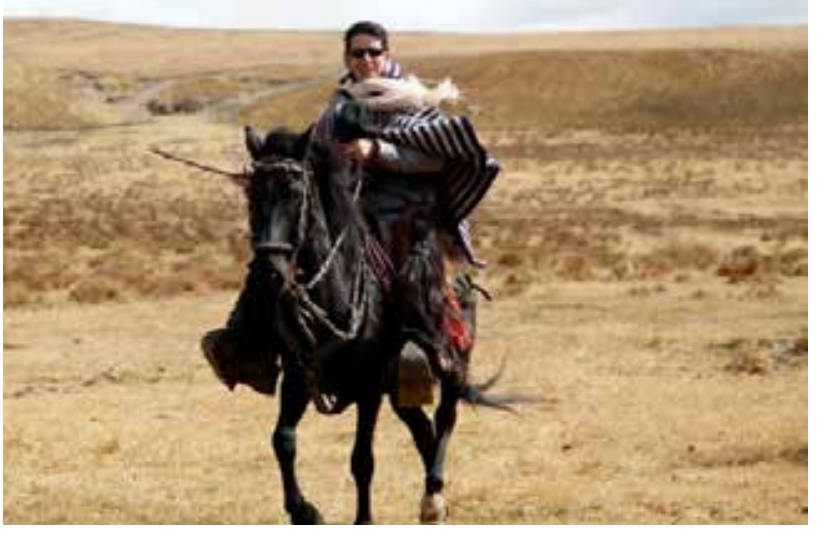

Paúl Rivas

Foto de José Simbaña / El Comercio Píntag, Ecuador 


\section{La frontera en el lente de Paúl Rivas}

El fotógrafo Paúl Rivas Bravo y el conductor Efraín Segarra Abril formaron parte de un equipo periodístico que durante el mes de marzo de 2018 realizó un viaje por el perfil costanero de Esmeraldas y parte de Manabí, para publicar reportajes sobre temas de seguridad. 


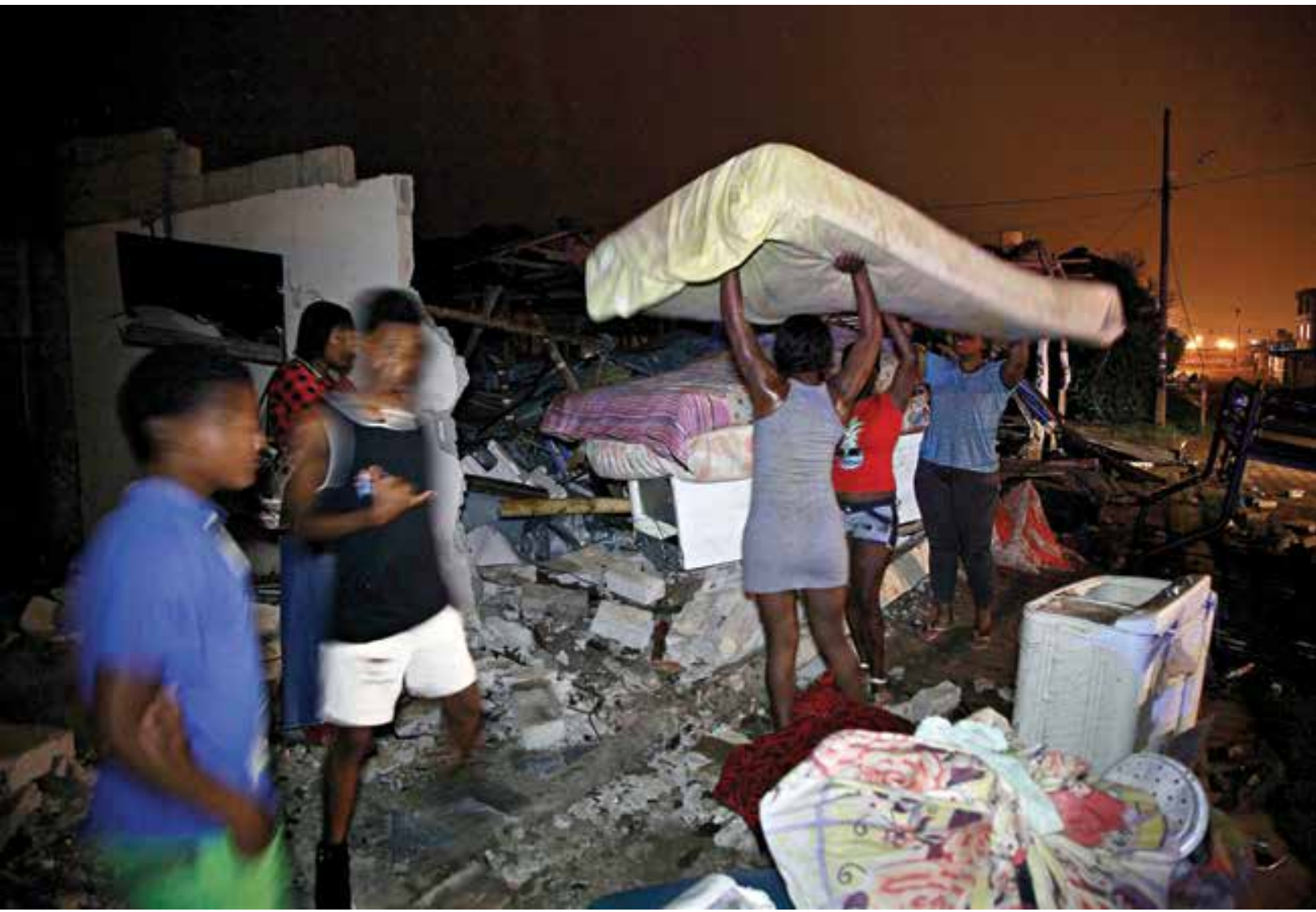

En la zona cercana a la

explosión, y junto a los

escombros de las viviendas

destruidas, se levantó un

albergue improvisado en la iglesia de San Lorenzo.

San Lorenzo, Esmeraldas

07/02/2018 


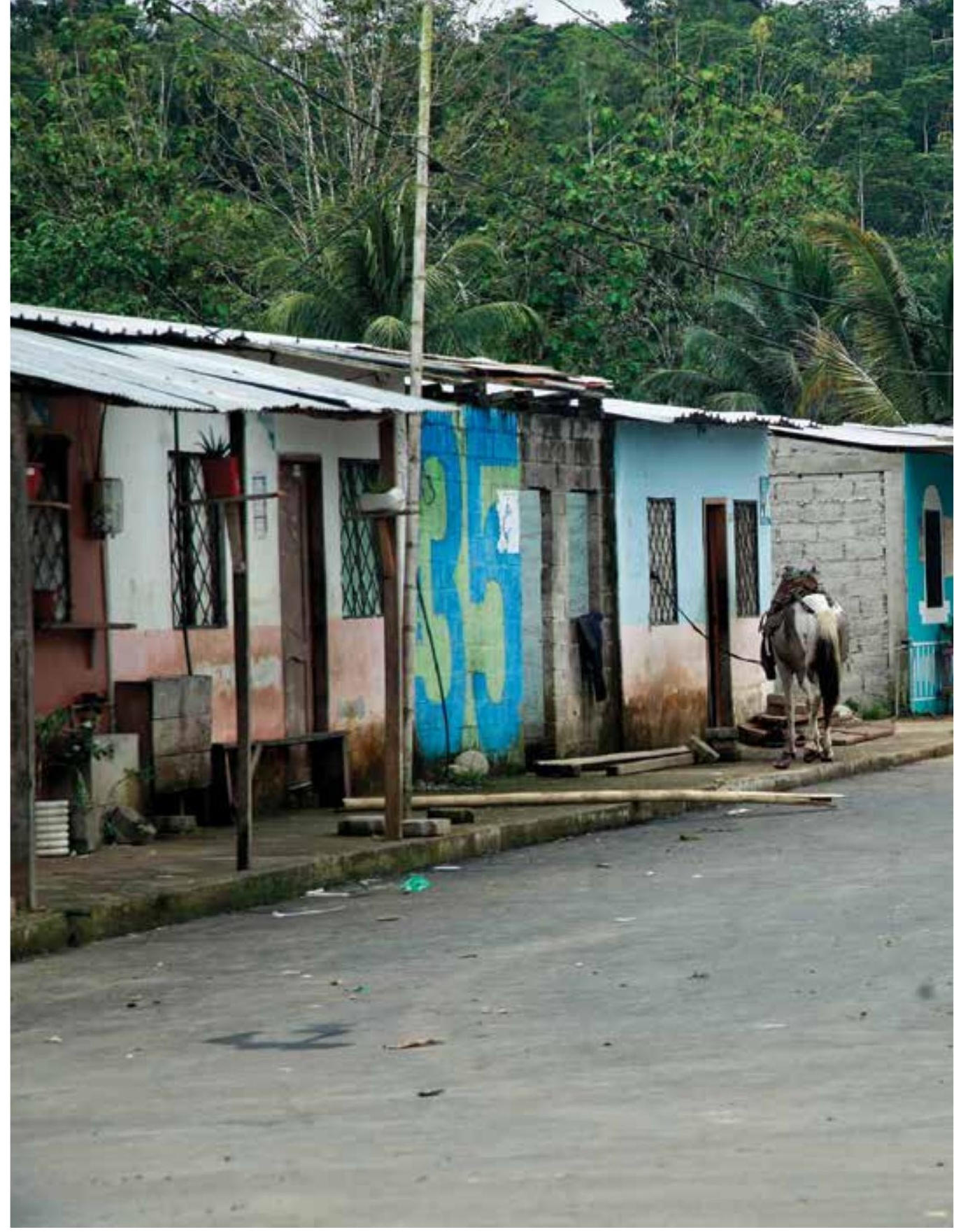

Las casas pequeñas, de una sola planta, con techos de zinc y soportes de madera caracterizan al poblado de Mataje. Está ubicado en plena frontera con Colombia. Mataje, Esmeraldas 28/01/2018 


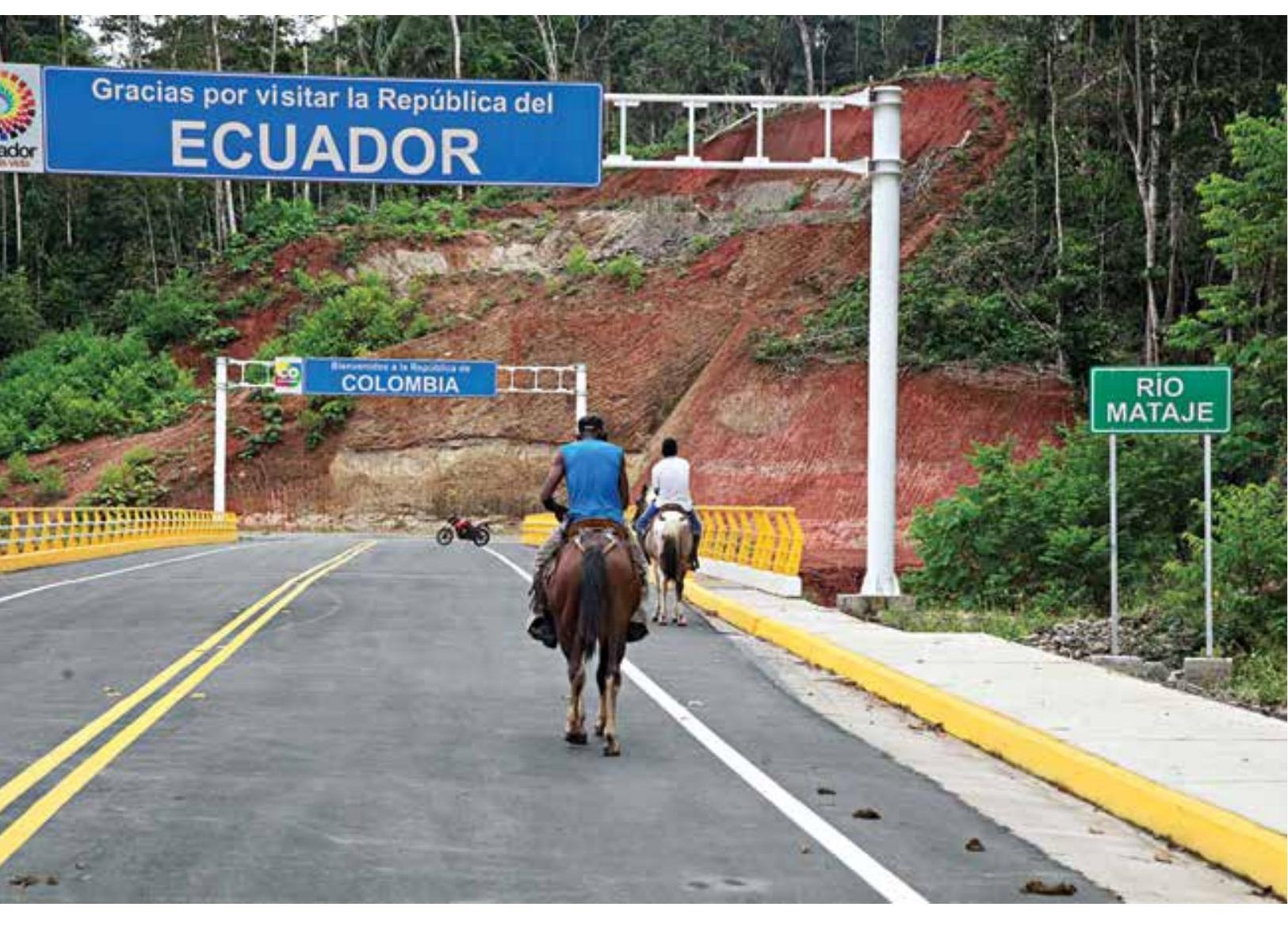

Una carretera asfaltada y

señalizada en su totalidad

es el límite entre Ecuador

y Colombia, en Mataje. El

camino conduce a una mon-

taña que está en territorio

colombiano.

Mataje, Esmeraldas

28/01/2018 
El poblado de Limones es la cabecera cantonal de Eloy Alfaro y está ubicado en una isla. Hasta allí solo se llega en lanchas que salen desde San Lorenzo.

Mataje, Esmeraldas

$29 / 01 / 2018$

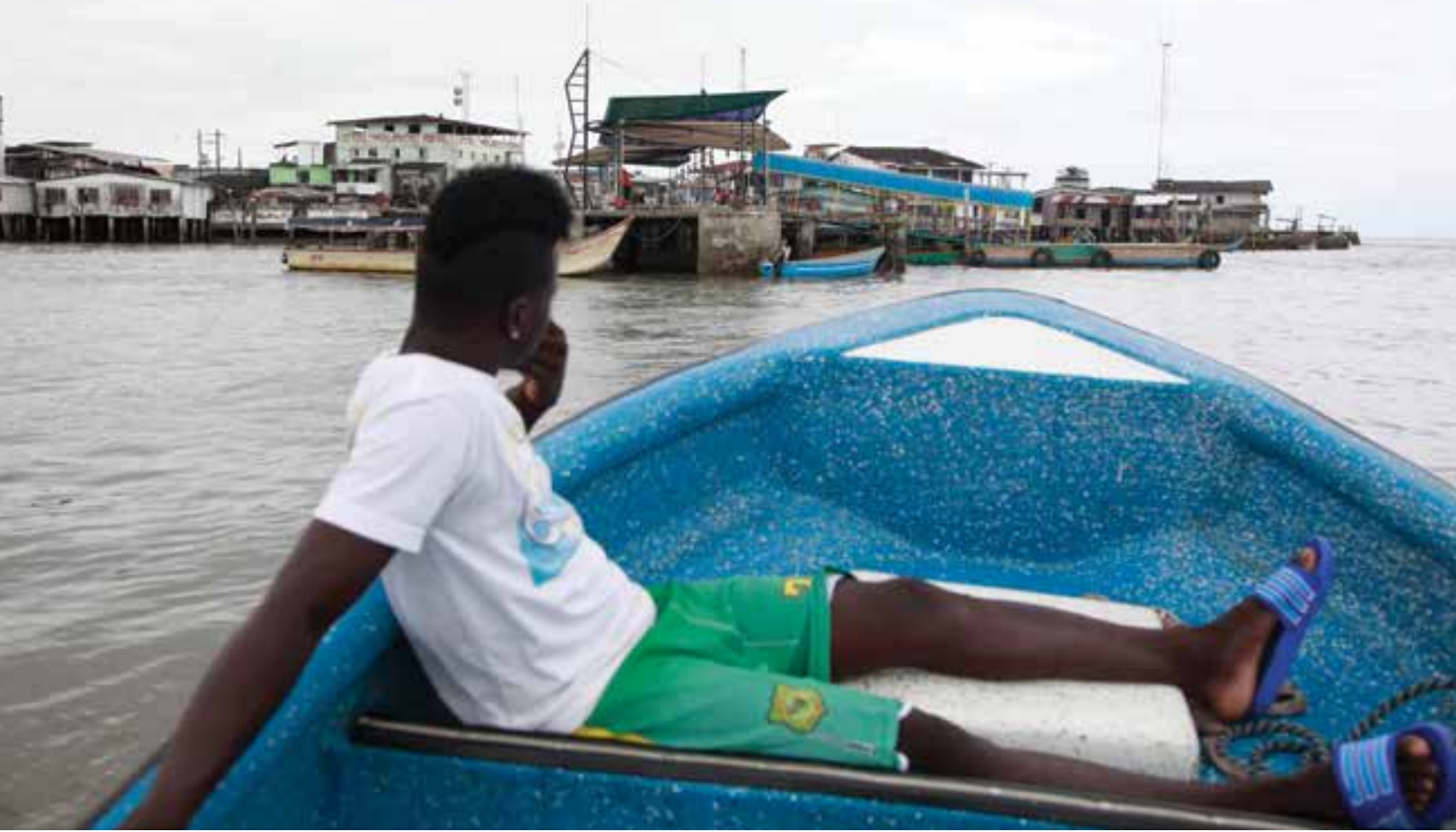




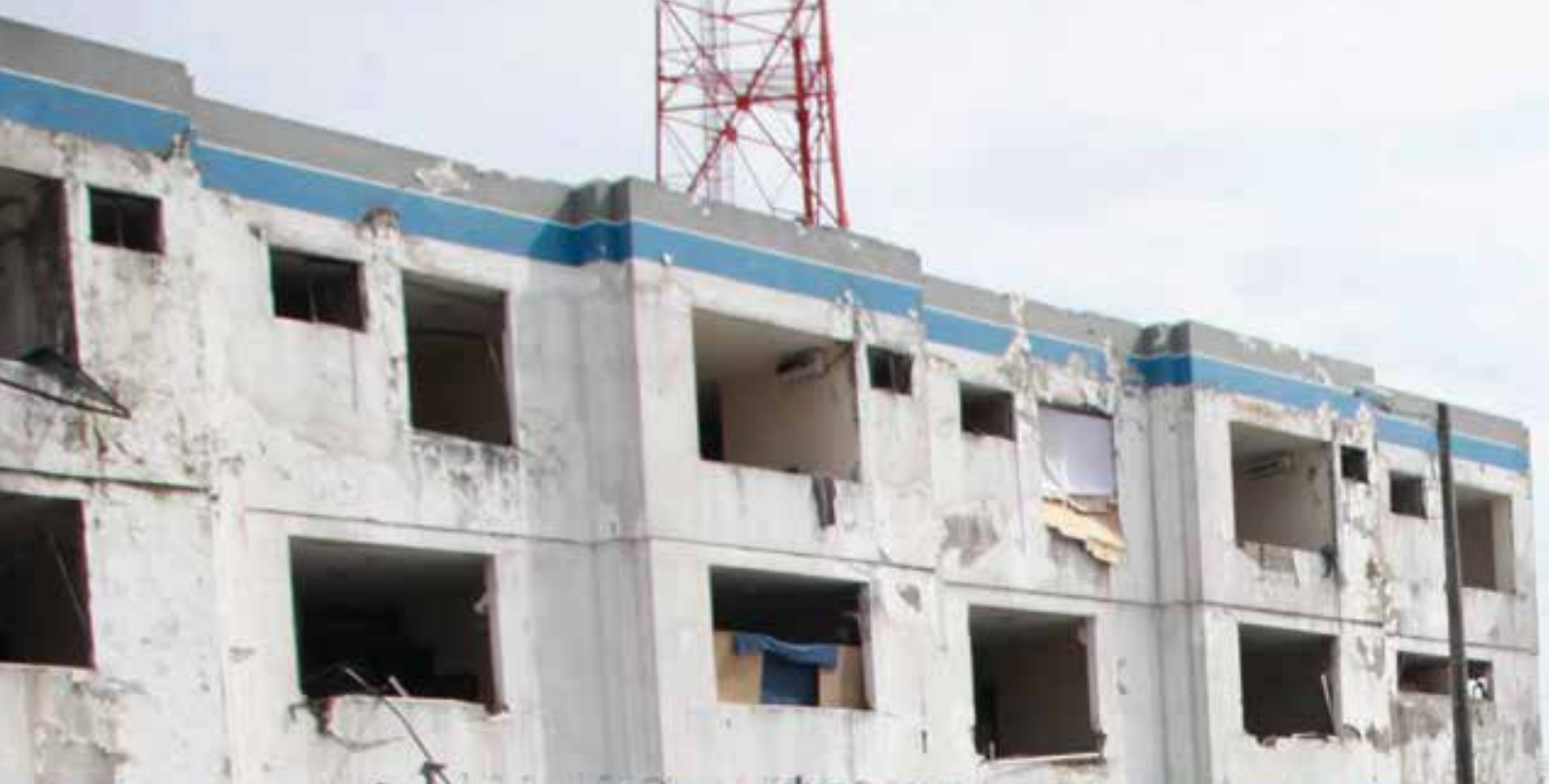




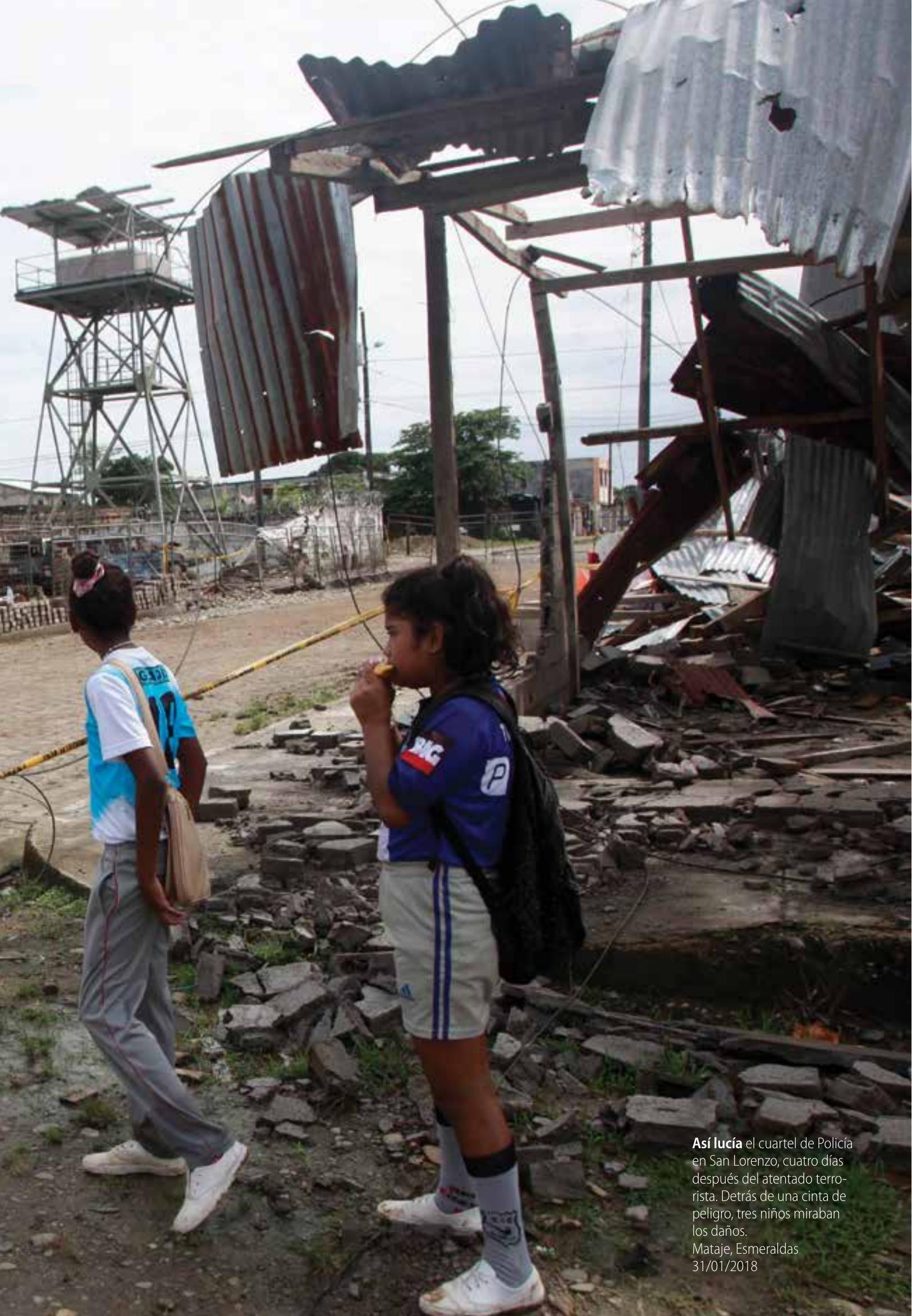




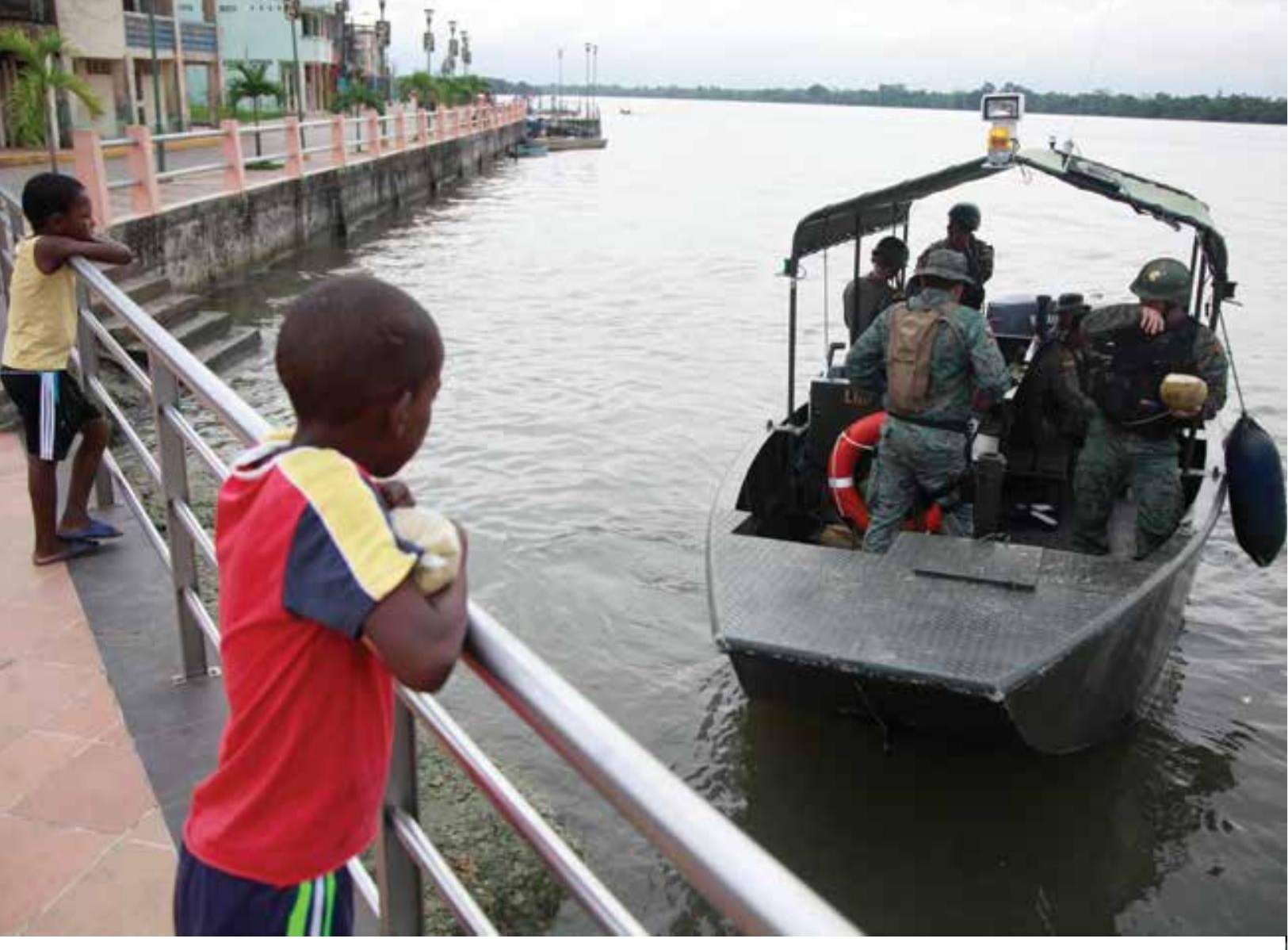

Desde el muelle, dos niños

de Borbón miraban a una

embarcación de la Marina que

salía a realizar un patrullaje.

Borbón, Esmeraldas

01/02/2018 
Pobladores de Puerto

Palma, en Nariño, en el sur de

Colombia.

Nariño, Colombia

01/02/2018

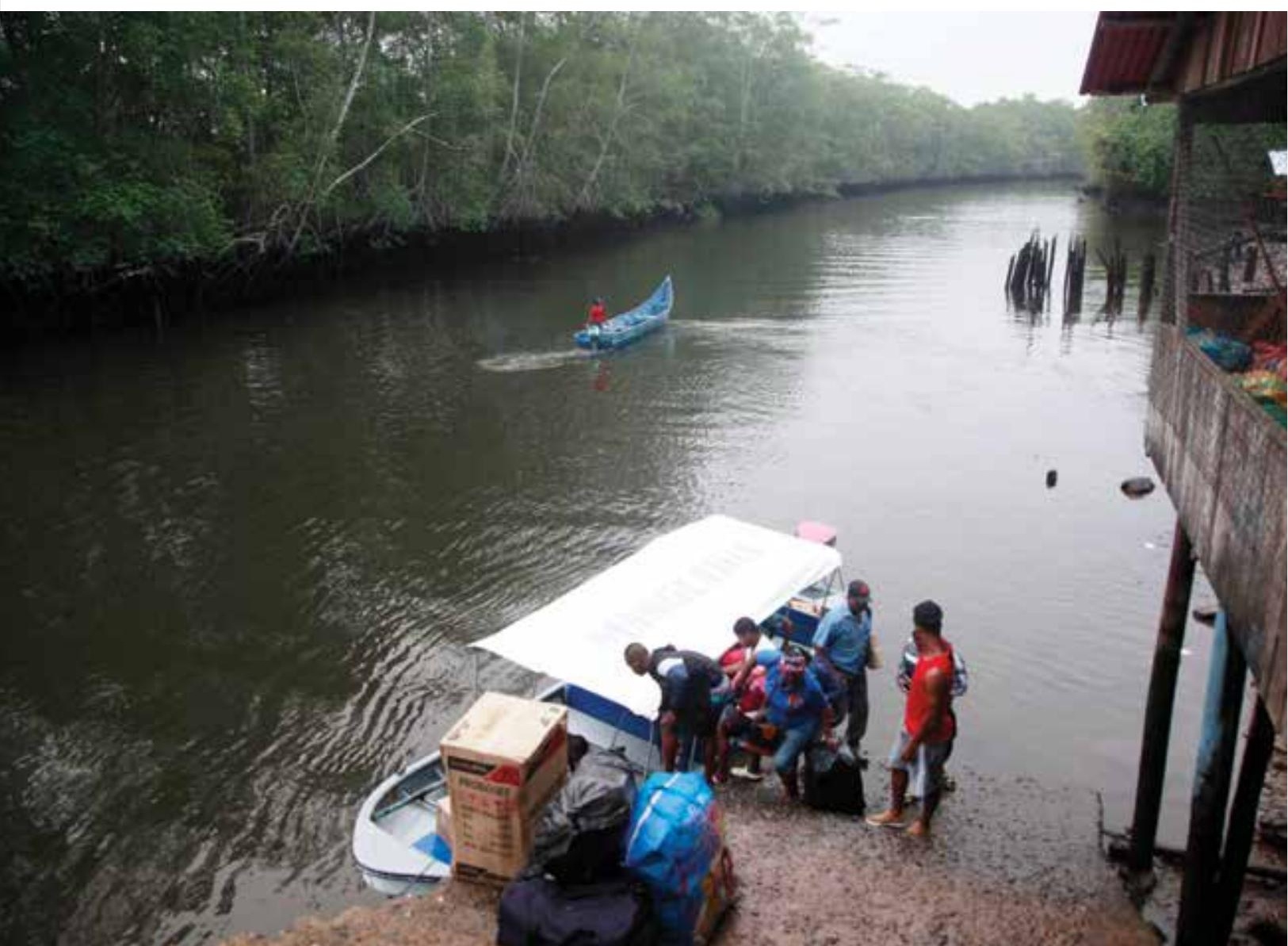











Personal de la Marina de

Colombia patrullaba el sector de Puerto Palma, cinco días después del atentado en el cuartel policial del poblado fronterizo ecuatoriano de San Lorenzo.

Nariño, Colombia 01/02/2018 


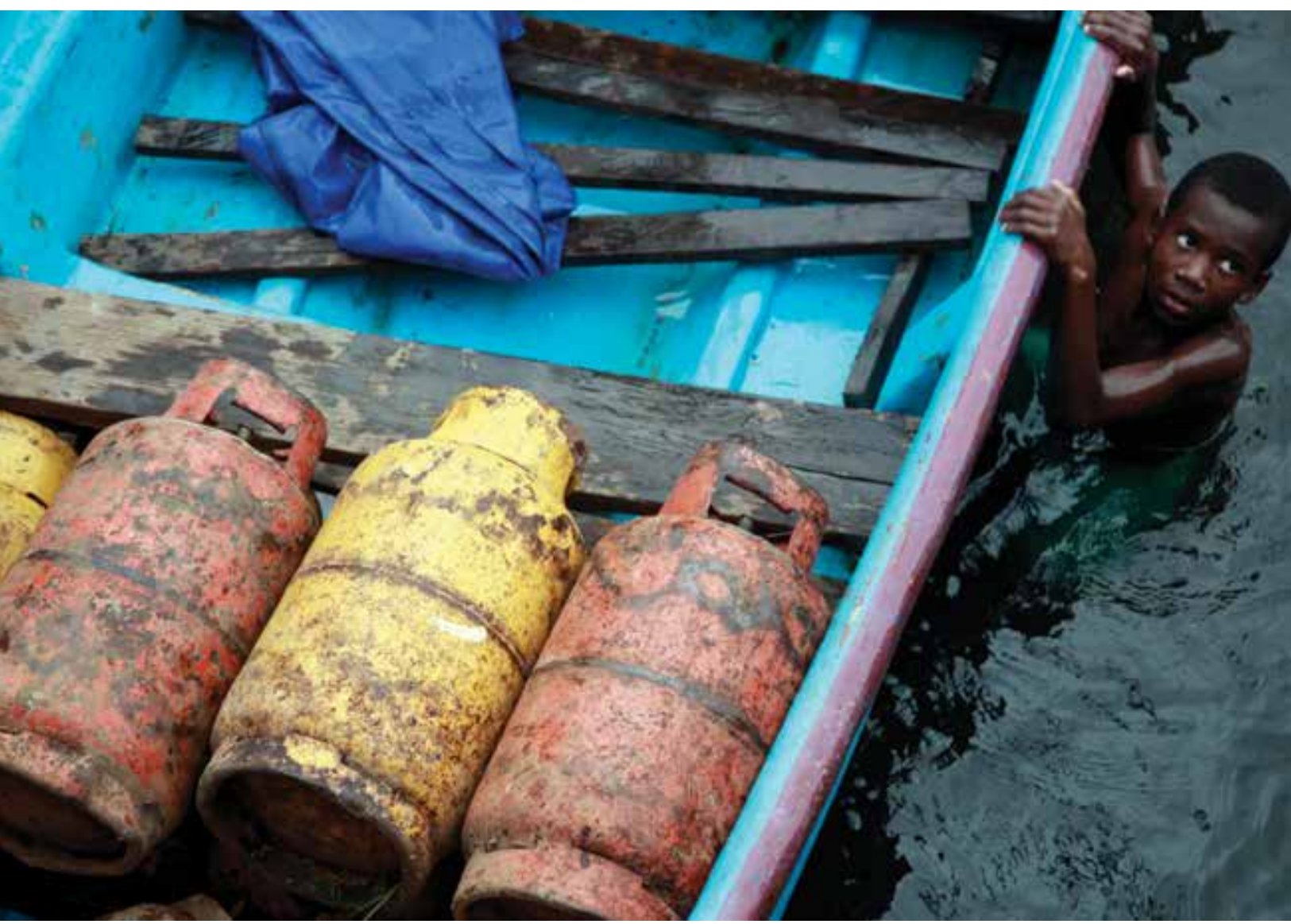

En Borbón, desde el agua

un niño sostenía esta embar-

cación en la que se transpor-

taban cilindros de gas.

Borbón, Esmeraldas

01/02/2018 
Detrás del recinto Olmedo hay una playa abandonada.

Allí estaban ocultas unas canecas de plástico, con olor a combustible.

Esmeraldas, Ecuador 03/2018

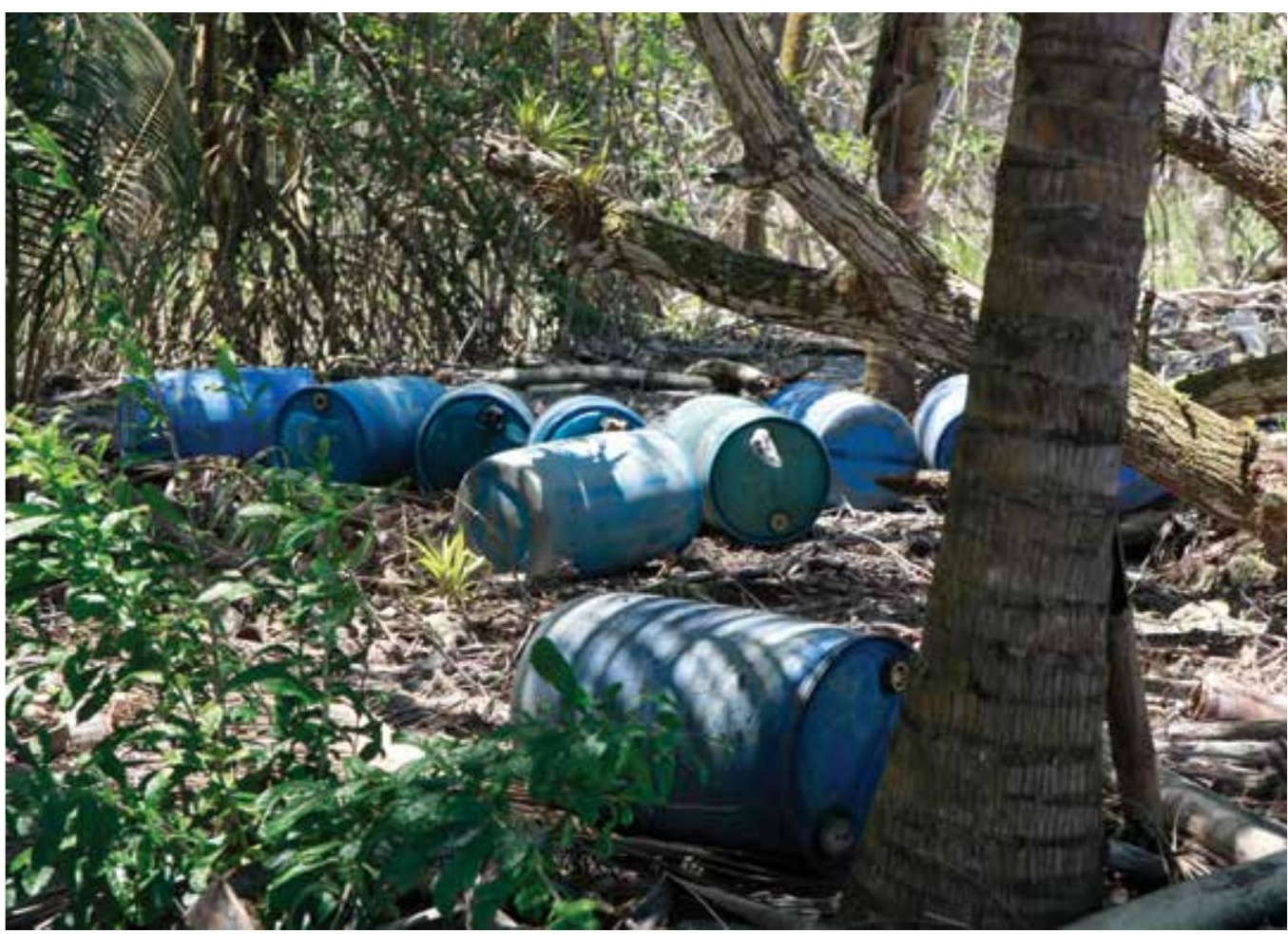




\section{Los reportajes de Javier Ortega}


Javier Ortega Reyes realizó once coberturas en la frontera entre Ecuador y Colombia, desde el 2013. Era un reportero metódico, apasionado, prudente y dedicado que investigó durante ocho años temas de seguridad y justicia. La violencia en el límite colombo-ecuatoriano se registró en varios de sus reportajes. De hecho, Javier estuvo en la última convención armada de las FARC, en los Llanos de Yarí, en septiembre del 2016. En varios reportajes de ese año resaltó el temor de autoridades y pobladores por lo que podría pasar con los milicianos que no se acogieran al proceso de paz que los comandantes de la guerrilla acordaron con el Gobierno colombiano. En esta muestra se recogen dos de ellos.

Otros cuatro trabajos que Javier publicó en El Comercio fueron levantados durante dos viajes que realizó en enero del 2018, tras la explosión de un coche bomba en las afueras del cuartel de Policía de San Lorenzo, Ecuador.

En su tercer viaje, que empezó el 25 de marzo de ese año, Javier fue secuestrado junto a sus amigos y compañeros de trabajo, Paúl Rivas Bravo y Efraín Segarra. Los tres fueron asesinados el mes de abril. 


\section{Jueves, 22 de febrero de 2018 : pobladores abandonan El Pan tras ataque}

En este reportaje, Javier pone en evidencia los temores que ya existían en

Mataje y otros poblados fronterizos por la amenaza de los grupos disidentes. El Pan fue evacuado casi en su totalidad y la gente solo quería volver para recoger sus cosas. Habían sido testigos de enfrentamientos armados entre uniformados y grupos irregulares. Era el 22 de febrero, un mes antes del secuestro del autor de este reportaje junto a sus compañeros Paúl Rivas y Efraín Segarra, y ya los líderes de Mataje advertían sobre la preocupación en poblados como ese y La Cadena. Los pobladores pidieron intervención del Gobierno ecuatoriano. Este, a su vez, admitió que la dinámica en la frontera cambió a raíz del proceso de paz entre su par colombiano y las FARC.
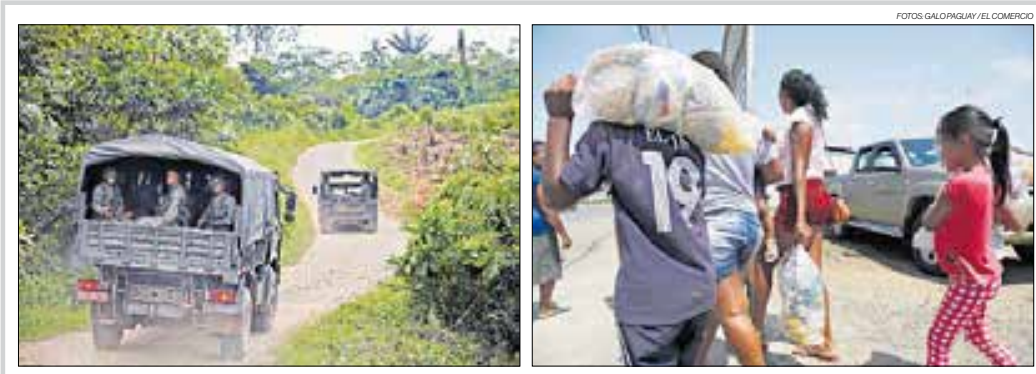

- Militares resguardan el ingreso a la población fronteriza de EI Pan, en San Lorenzo.

- Familias enteras Ilegaron a San Lorenzo, luego de los ataques en EI Pan.

FRONTERA 200 personas llegaron a San Lorenzo. FF.AA. y Policía integraron un mando unificado.

\section{Pobladores abandonan El Pan tras ataque}

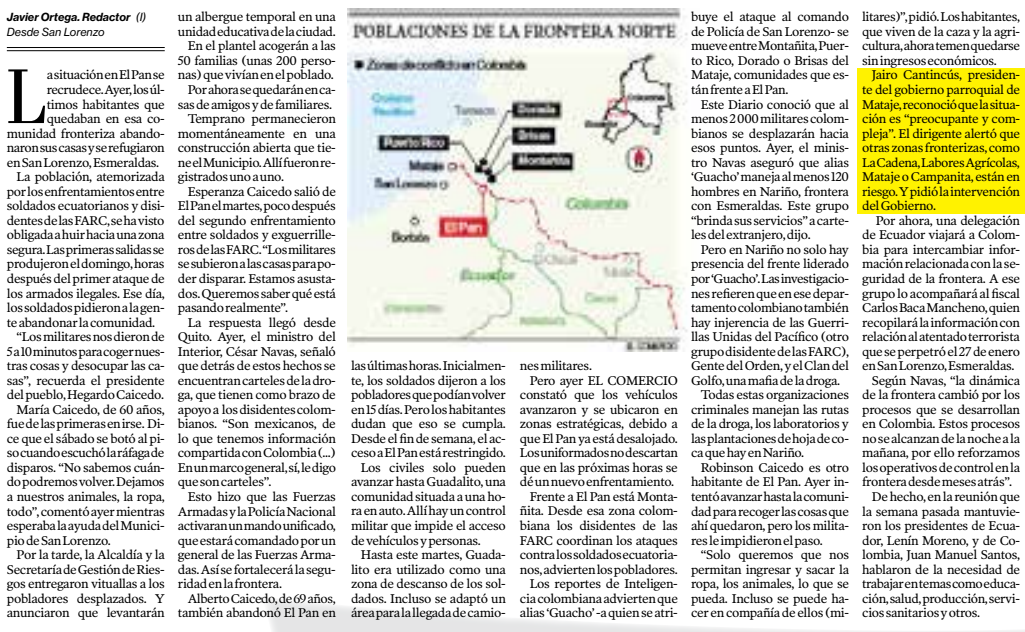

"Jairo Cantincús, presidente del gobierno parroquial de Mataje, reconoció que la situación es "preocupante y compleja". El dirigente alertó que otras zonas fronterizas, como La Cadena, Labores Agrícolas, Mataje o Campanita, están en riesgo. Y pidió la intervención del Gobierno”. 


\section{Domingo, 25 de febrero de 2018: tres bandas operan en San Lorenzo}

El temor por los enfrentamientos armados entre militares ecuatorianos y colombianos con grupos irregulares atemorizaba a poblados a ambos lados de la frontera. En este reportaje, Javier revela que, además del Frente Oliver Sinisterra, al cantón ecuatoriano de San Lorenzo le afectaban las actividades de Guerrillas Unidas del Pacífico y el Clan del Golfo.

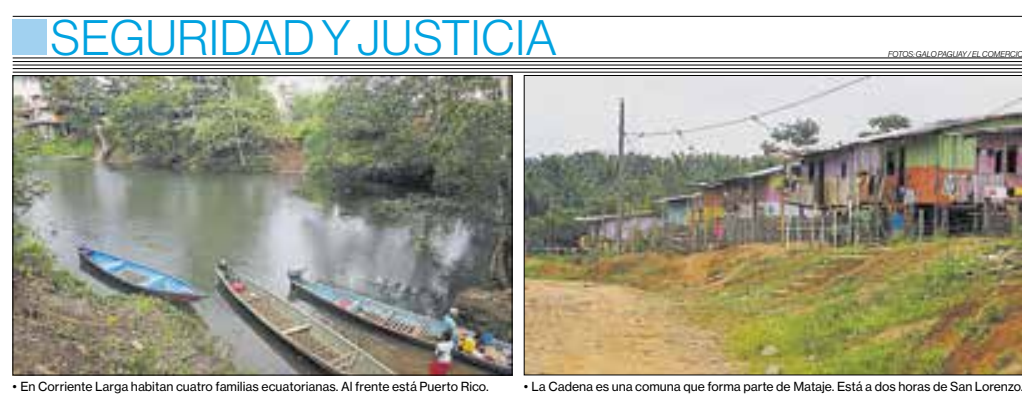

INFORME Oliver Sinisterra, Guerrillas Unidas del Pacífico y Clan del Golfo ocupan terreno colombiano

\section{Tres bandas operan frente a San Lorenzo}
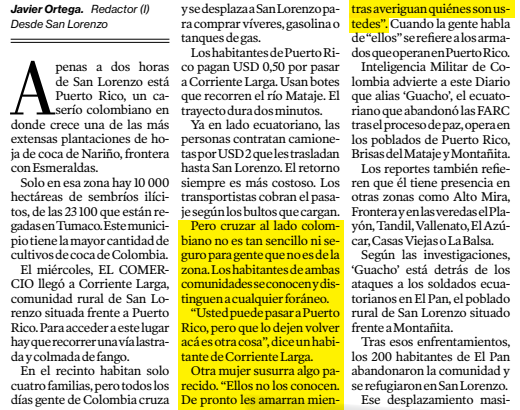

vopreocupaalagentedeotras

entreunoy otropueblo. flicto colombiano, señala que CosmastatronClandel Golfo se ha asocía centes de violencia comolos frenteoliverSinisterraliaderacon las GUP paracontrol registradosen El Pan.
Eso lo admite Jairo Cantin--
Losin informes revelan que el cús, dirigente parroquial de Clandel Golfo, unamafiadednas: Mataje Alto, ElPan, Labo- renciaencomunidadesubicares Agricolas, La Cadena, Ma- das en el occidente de la fron-
taje, Valverde, Las Delicias, tera con Fsmeraldas. Desde os situaciones: la primer. viencen una disputa armada y la segunda, que las GUP se
subordinen al Clan del Golfo, Lelicias, tera con Esmeraldas. Desde debido a su amplia capacidad yCorriente Larga. ciones cargadas condroga ha- En Corriente Larga la gente Paraellider, Mataje Alto,La- ciael Pacífico.
bores Agricolas, La Cadena y
Hasta octubre pasado, esa

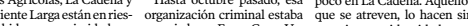
fronteracon Colombia. Mataje Alto, por ejemplo, es Las Guerrillas Unidas del do, en Puerto Rico, hay decena de las comunidades más Pacífico (GUP) es otro de los nas de parcelas de plantacio-

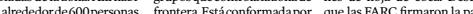
Desde los enfrentamientos unos 250 hombres, principal- y abandonaron estos territoel fin de semana, el paso aes- mentedisidentesdelasFARC. rios, los nuevos grupos armalugarestárestringido,como Uninforme dela Fundación dos custodian los terrenos y cuatrofamilias, perotodos los recido. "Elllos no los conocen. serefugiaronen San Lorenzo. ocurre con El Pan. Hay unos Paz y Reconciliación, una or- dan protección a los n-

"Pero cruzar al lado colombiano no es tan sencillo ni seguro para gente que no es de la zona. Los habitantes de ambas comunidades se conocen y distinguen a cualquier foráneo. "Usted puede pasar a Puerto Rico, pero que lo dejen volver acá es otra cosa", dice un habitante de Corriente Larga. Otra mujer susurra algo parecido . "Ellos no los conocen. De pronto les amarran mientras averiguan quiénes son ustedes". 


\section{Efraín Segarra, un guerrero sobre ruedas}


El factor más importante para que un buen reportaje salga a la luz es el trabajo en equipo. La confianza, el cariño, el apoyo, la solidaridad, la lealtad son elementos que deben existir en un grupo que se enfrenta cada día a la noticia desde diferentes ángulos y con sus complejidades. Eso lo aprendieron decenas de reporteros y fotoperiodistas de El Comercio, durante los dieciséis años que tuvieron la oportunidad de compartir caminos con Efraín Segarra Abril.

En este mapa solo se registran algunos de los incontables destinos a los que Efraín llevó seguros a varios equipos de ese medio de comunicación ecuatoriano. En el 2018, él llevó a Paúl Rivas y al reportero Fernando Medina por el perfil costanero de Esmeraldas y parte de Manabí, para realizar un reportaje sobre seguridad en esa zona. El viaje se planeó para continuar informando sobre la tensa situación que se vivía en la frontera colombo-ecuatoriana tras el atentado en contra del cuartel policial del cantón esmeraldeño de San Lorenzo.

Los tres trabajaron en largas jornadas por poblados abandonados por el Estado y regresaron a salvo cada noche a sus sitios de hospedaje y volvieron a Quito con excelentes trabajos periodísticos. El 25 de marzo del 2018, Efraín llevó nuevamente a Paúl, esta vez junto al periodista Javier Ortega. Los tres llegaron juntos de Quito a San Lorenzo. El 26 de marzo, juntos planearon un día de reportería, juntos pasaron por un retén de la Marina con dirección a Mataje y con la autorización de oficiales de la zona. Juntos fueron secuestrados minutos después en territorio ecuatoriano. Efraín puso en práctica hasta el final los consejos que compartió con muchos de sus compañeros: el trabajo debe ser en equipo, para ayudarse y cuidarse siempre... hasta el final. 


\section{Segarrita, \\ un guerrero sobre ruedas}

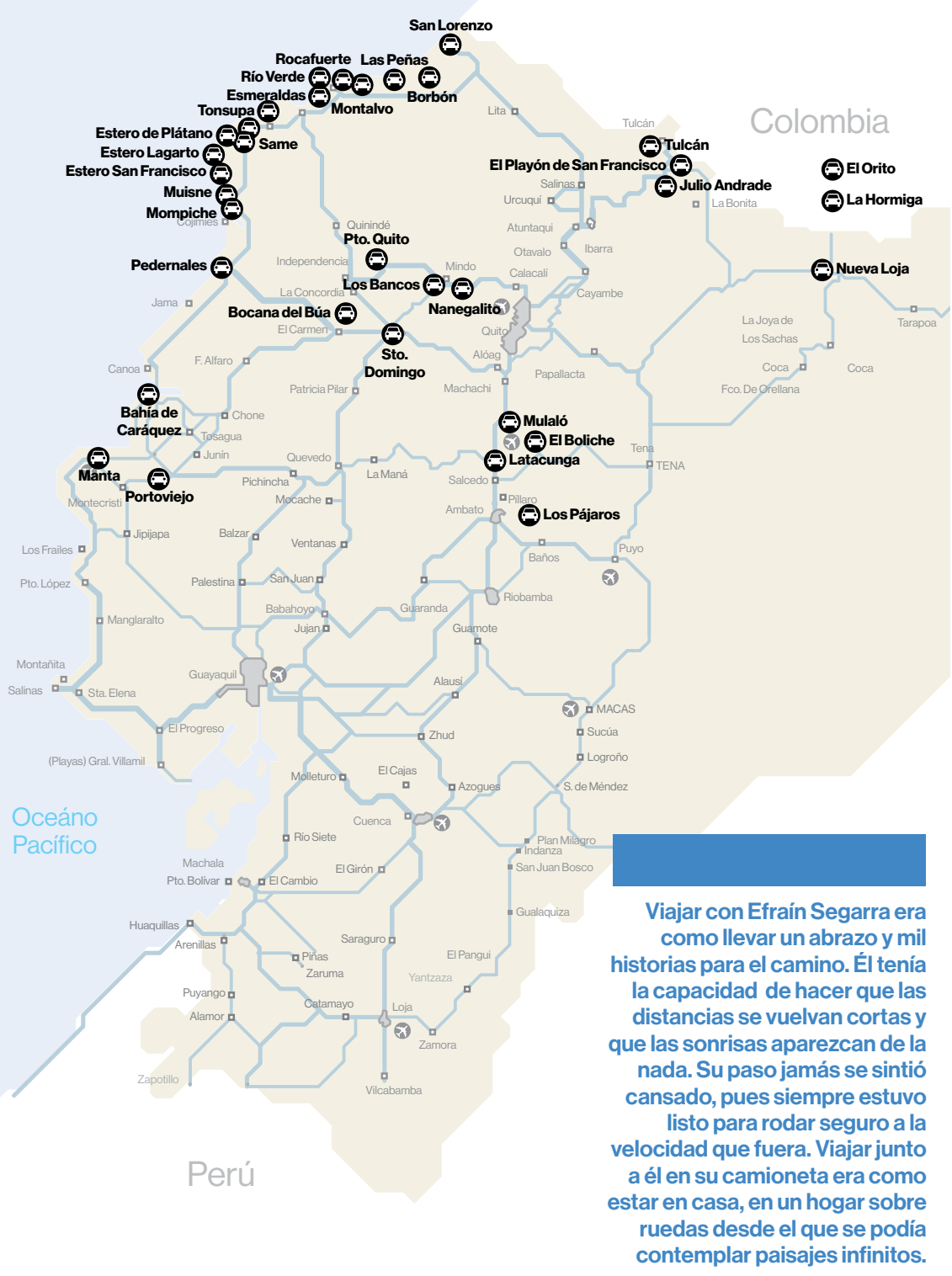

